https://nv.nltu.edu.ua

https://doi.org/10.36930/40310218

ISSN 2519-2477 (online)

Article received 01.03.2021 p.

Article accepted 29.04.2021 p.

$@ \bowtie$ Correspondence author

UDC 621.9.048.6

S. E. Liaskovska

solomiam@gmail.com

О. Т. Велика ${ }^{1}$, С. Є. Лясковська ${ }^{1}$, О. О. Смотр ${ }^{2}$, М. В. Бойко ${ }^{1}$

${ }^{1}$ Національний університет "Львівська політехніка", м. Львів, Україна

${ }^{2}$ Львівський державний університет безпеки життєдіяльності, м. Львів, Україна

\title{
ІМІТАЦІЙНЕ МОДЕЛЮВАННЯ ТЕХНОЛОГІЧНОГО ПРОЦЕСУ ВИГОТОВЛЕННЯ ВИРОБІВ У СЕРЕДОВИЩІ FLЕXSIM
}

Наведено алгоритм аналізу технологічного процесу на виробництві з використанням середовища імітаційного моделювання FlexSim. Проаналізовано задачу, яка розв'язує процес сортування та упакування виробів. Побудовано модель поведінки системи, яка дає змогу виявити проблемні ділянки, нештатні ситуації на виробництві, враховувати вхідні параметри. Для цього попередньо проаналізовано низку методів і засобів для моделювання процесу. Показано ефективність вибору показникового закону розподілу виробів зі складу на станції. З'ясовано, що закон розподілу має значення для побудови імітаційної моделі. Він дає змогу забезпечити рівномірне навантаження на станції, куди відсортовуються вироби, щоб запобігти простою чи нерівномірному навантаженню на кожну зі станцій. Виробничу задачу розв'язано в середовищі FlexSim, де побудовано імітаційну модель процесу. Розглянуто частину технологічного процесу для виготовлення обладнання на виробництві: етапи розвантаження, розкомплектування палет, відбраковування виробів та комплектації замовлення. Моделювання процесу в середовищі FlexSim здійснено із врахуванням поданих параметрів і зв'язків між ними. Побудована імітаційна модель дала змогу проаналізувати етапи розподілу виробів та обрати раціональніший. Проаналізовано результативність застосування показникового закону розподілу виробів зі складу на станції. У процесі розроблення імітаційної моделі проаналізовано вплив різних даних як на кожен об'єкт зокрема, так і на систему загалом. Подано схему взаємозв'язків між параметрами моделі та відображення даних, які впливають на кожен об'єкт зокрема. Встановлено, що взаємозв'язки між різними об'єктами моделі дають змогу проаналізувати як можна змінити логіку процесу, щоб оптимізувати технологічний процес. Запропоновано алгоритм послідовного введення даних та визначення логіки руху об'єктів на кожному етапі моделювання досліджуваного процесу.

Ключові слова: імітаційна модель; технологічний процес; виробництво; показниковий закон розподілу; промисловість.

\section{Вступ}

Сучасні інформаційні технології надають могутній поштовх еволюції процесів виробництва і промисловості. Оброблення значних обсягів інформації, робота 3 даними в реальному часі, використання великих потоків даних на виробництві дає змогу ефективно використовувати ресурси підприємства для виготовлення більшої кількості товарів із меншими затратами, ефективно планувати ресурси. Це сприяє збільшенню доходів від виробництва. Планування та організація процесів створення виробів від креслення, 3D моделі до процесу його дизайну, що застосовують до виробів, товарів масового виробництва, - це етапи, які потребують насамперед реального і чіткого планування. Залучення інформаційних графічних технологій, математичного та геометричного моделювання дає можливість враховувати вхідні та вихідні параметри процесу, взаємозв'язки між об'єктами на виробництві, затрачений час та вплив функціональних чинників на кожен етап проєктування і виробництва, починаючи від дизайну, створення виробу, перевірки на якість до випуску товарів для споживача, екологічний вплив на зовнішнє середовище, можливість вторинного перероблення тощо. Важливими $\epsilon$ інші етапи виробництва: перевірка на якість як пілотного взірця виробу, так і товарів, які виготовлені на продаж. Планування є першим етапом для створення та випуску продукції, а їі дослідження та розроблення ефективне за умови залучення засобів моделювання перелічених процесів, зокрема імітаційного моделювання. Наголосимо, що модель, створена у середовищі FlexSim, демонструє вплив вхідних даних одного об'єкта на перебіг усього технологічного процесу виробництва. Інформаційні технології, математичне та геометричне моделювання $є$ ефективним засобом, що змінюють якість роботи підприємства. Імітаційне моделювання, матема-

Інформація про авторів:

Велика Оксана Тарасівна, канд. техн. наук, доцент, кафедра проектування та експлуатації машин. Email: veloks@ukr.net; https://orcid.org/0000-0003-1575-8829

Лясковска Соломия Евгеньевна, канд. техн. наук, доцент, кафедра проектування та експлуатації машин. Email: solomiam@gmail.com; https://orcid.org/0000-0002-0822-0951

Смотр Ольга Олексіївна, канд. техн. наук, доцент, кафедра інформаційних технологій та телекомунікаційних систем, полковник служби цивільного захисту. Email: o.smotr@ldubgd.edu.ua; https://orcid.org/0000-0003-2767-5019

Бойко Михайло Васильович, ст. викладач, кафедра проектування та експлуатації машин. Email: osnastka@ukr.net

Цитування за ДСту: Велика, О. Т., Лясковська, С. Є., Смотр, О. О., Бойко, М. В. Імітаційне моделювання технологічного процесу виготовлення виробів у середовищі FlexSim. Науковий вісник НЛтУ України. 2021, т. 31, № 2. С. $108-113$.

Citation APA: Velyka, O. T., Liaskovska, S. E., Smotr, O. O., \& Boyko, M. V. (2021). Simulation modeling of technological process of manufacturing in FlexSim environment. Scientific Bulletin of UNFU, 31(2), 108-113. https://doi.org/10.36930/40310218

108 Науковий вісник НЛТУ України, 2021, т. 31, № 2 Scientific Bulletin of UNFU, 2021, vol. 31, no 2 
тичний опис процесу з використанням 3D геометричних моделей у просторі показали, що ефективний технологічний процес складається з багатьох чинників, які взаємодіють між собою. Дослідження впливу функціональних параметрів, зокрема на роботу системи, $\epsilon$ ефективним при залученні математичного та геометричного моделювання, де спостерігається загальна картина роботи технологічної системи на виробництві. Це потребує залучення засобів формування загальної моделі роботи системи. Результати моделювання дають змогу отримати оптимальне рішення для уникнення неполадок, підвищення ефективності використання ресурсів тощо. Необхідним $є$ використання інформаційних технологій та моделювання для отримання управлінського рішення. Воно має бути ефективним, щоб мінімізувати часові та фінансові витрати. Зазначимо, що в потоковому виробництві досягається висока продуктивність праці завдяки безперервності процесу виготовлення продукції, забезпечується належна іiі якість при економії затрат праці, матеріальних та енергетичних ресурсів порівняно з непотоковим виробництвом.

Об'єкт дослідження - технологічний процес виготовлення штампів для обладнання різного типу.

Предмет дослідження - імітаційна модель технологічного процесу виготовлення штампів

Мета роботи - розроблення та аналіз імітаційної моделі технологічного процесу виготовлення штампів для оптимізації виробничих етапів процесу.

Для досягнення зазначеної мети визначено такі оcновні завдання дослідження: створити імітаційні моделі технологічних процесів виготовлення виробів; проаналізувати вхідні дані та вихідні результати; опрацювати моделі поведінки технологічних систем на виробництві у середовищі FlexSim; спрогнозувати майбутню поведінку системи (технологічного процесу) за допомогою створеного алгоритму.

Наукова новизна отриманих результатів дослідження - вперше реалізовано алгоритм побудови імітаційної моделі для технологічного процесу виготовлення штампів із залученням показникового закону розподілу. Наведено послідовність задавання логіки для взаємодії об'єктів цього технологічного процесу. Це дасть змогу рівномірно розподілити вироби на першому етапі виробництва і запобігти перевантаженню чи простою кожної черги (Queue1, Queue2, Queue3, Queue4).

Практична значущість результатів дослідження розроблений підхід дає змогу планувати та створювати практичні приклади роботи виробництва, підбирати відповідні параметри та аналізувати вхідні та вихідні дані в досліджуваній системі.

Аналіз останніх досліджень і публікацій. Для дослідження процесів на виробництві використано принцип імітаційного моделювання, що є ефективним методом дослідження технологічних систем і процесів [5]. У спеціальних середовищах створюємо імітацію процесів на виробництві, використовуючи логіку для кожного об'єкта зокрема. Створена модель може досліджувати роботу виробництва в часі та отримати статистику процесів.

Залучені засоби середовища FlexSim компанії FlexSim Software Products [5] здатні будувати імітаційні моделі та аналізувати результати під час моделювання.

Перед сучасними підприємствами часто постає завдання виконати комплексне дослідження ефективності функціонування та оптимізації технологічних процесів на виробництві, зокрема на потоковому виробництві. Використаний програмний інструментарій [5] дає змогу створювати моделі виробничо-технологічних систем, обчислювати показники процесу функціонування системи в режимі реального часу. Об'єктами моделювання FlexSIM можуть виступати як технологічна система загалом, так і їі елементи зокрема [5], деякі технологічні процеси $[4,5]$, потокові лінії, функції та взаємозв'язки між ними [9]. Проте у зазначених наукових розвідках немає аналізу розподілу і впливу їх на перебіг технологічних процесів. Поняття потокового виробництва у нашому дослідженні розуміємо як таку форму організації виробництва, за якої ритмічно повторюються погоджені в часі основні та допоміжні операції, які виконуються на спеціалізованих робочих місцях, розташованих у послідовності операцій технологічного процесу [2, 3]. Тут дослідження обмежуються частинним аналізом процесу. Зазначений напрямок моделювання технологічних процесів на виробництві розкрито у дослідженні [1]. Для такого технологічного процесу виробництва характерне ланцюгове розташування робочих місць відповідно до ходу технологічного процесу, що унеможливлює зворотний рух об'єктів, які виготовляються, безперервність передачі їх з однієї операції на іншу або одночасне виконання декількох операцій із застосуванням багатофункціональних машин, яке варто врахувати під час моделювання таких технологічних процесів.

Основною ланкою потокового виробництва $\epsilon$ потокова лінія, яка $є$ групою робочих місць, за якою закріплено виготовлення одного або обмеженої кількості найменувань предметів праці. Тому моделювання та управління потоковою лінією (конвеєрами) є однією 3 поширених задач масового виробництва $[1,8]$. У роботі [8] показано важливість врахування вимог до проєктованого обладнання щодо забезпечення споживацької якості та безпечності продукту належним вибором програмних засобів управління інформаційною та технологічною підтримкою процесу проєктування з урахуванням його життєвого циклу. Модель руху деталей по конвеєру описує показниковий закон розподілу для визначення інтервалів часу надходження деталей $[7,10]$. Показниковий закон моделюється за допомогою оберненої функції [6].

\section{Результати дослідження та їх обговорення}

Вищого рівня ефективності та якості управління архітектурою програм процесів проєктування стосовно обладнання на виробництві можна досягти використанням сучасних методів проєктно-орієнтованого управління на засадах інформаційних комп'ютерних технологій проєктування, реалізації вимог технічного дизайну, математичного, методичного та програмного забезпечення етапів процесу проєктування і виготовлення устаткування.

Важливою актуальною проблемою у забезпеченні продукцією харчової промисловості постає належна іiі якість та безпечність у використанні, що безпосередньо впливає на стан здоров'я споживачів, оскільки позитивний результат у запобіганні негативних наслідків споживання харчової продукції сумнівного походження залежить як від якості використовуваної харчової сировини, так і рівня технологічності обладнання, якості упакування, алгоритму технологічного процесу. 
Процес проєктування і виготовлення пілотного взірця обладнання враховує, на засадах проєктно-орієнтованого управління, життєві цикли програмних, наукових, дослідницьких складників підпрограм і проєктів. Процес проєктування обладнання базується на технічному завданні, в якому, зокрема, зазначені усі типи обладнання, необхідного для виготовлення харчової продукції. Під час створення, до прикладу м'ясної, хлібобу- лочної, молочної продукції, функціональними елементами процесу виступають машини та вузли підготовки вхідної сировини (борошно, м'ясо, молоко тощо), іiї перероблення (процес переміщення, збовтування, розділення тощо), які являють окремі складові підпрограм процесу виготовлення обладнання на підставі побудованого нами в середовищі $\mathrm{CAD}$ - системи Компас проєкту процесу виготовлення обладнання (рис. 1).

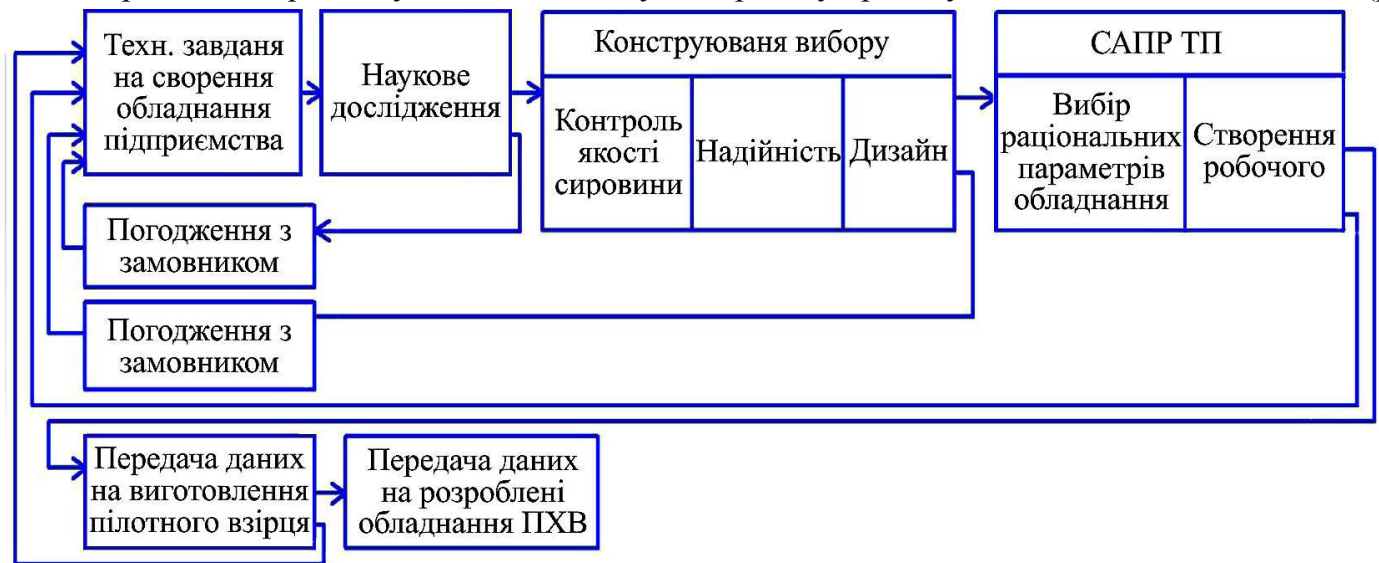

Рис. 1. Проєкт процесу виготовлення обладнання

Розглянемо технологічний процес виробництва виробів з використанням обладнання і переміщенням виробів у робочі позиції при виконанні певної послідовності операцій.

Наведемо опис технологічного процесу:

1. Виконуються послідовно дві операції.

2. Потокова лінія поміщає шість виробів (вироби є громіздкими), чотири вироби до першого робочого місця та два вироби до другого робочого місця.

3. Якщо немає місця на конвеєрі, то вироби, що надійшли, відкладаються.

4. Інтервали часу між надходженнями виробів розподілені експоненціально 3 математичним сподіванням 0,4 одиниці часу.

5. Тривалість оброблення в середньому становить 0,25 на першому робочому місці і 0,5 - на другому робочому місці.

Якщо черга до другого робочого місця повна, то блокується перше робоче місце. Потокову лінію схематично показано на рис. 2.

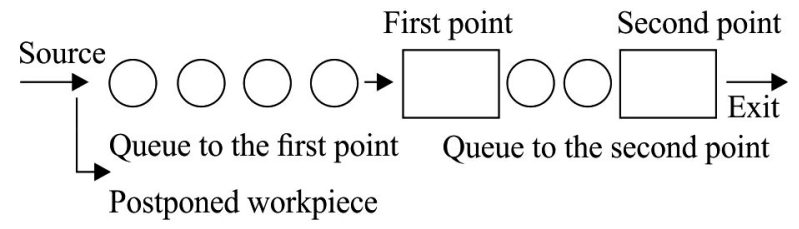

Рис. 2. Схематичне зображення потокової лінії

На її основі побудовано імітаційну модель потокової лінії технологічного процесу на виробництві (рис. 3), наведено приклад дослідження та аналіз її роботи впродовж певного інтервалу часу, наприклад 300 од. часу, за такими показниками:

- завантаження робочих місць;

- тривалість оброблення одного виробу на лінії;

- кількість виробів, оброблення яких відкладено;

- кількість виробів, що знаходяться в черзі до кожного робочого місця.

Розглянемо частину технологічного процесу виготовлення обладнання на виробництві. До складального цеху надходить продукція чотирьох типів. Тоді складання виробу здійснюється також у чотири етапи.
На першому етапі збираються проміжні вироби першого і другого типів. На другому етапі збираються проміжні вироби з деталей третього і четвертого типів. На третьому етапі вироби, отримані раніше, поєднуються в підсумковий виріб. Етапи перший і другий виконуються паралельно. Перший етап виконують двоє робітників, кожний $з$ яких завантажує товари на станцію перевірки якості. Після перевірки товари відбраковуються, $5 \%$ товарів рухається по конвеєра на окрему станцію "брак", інші якісні вироби рухаються на станцію "якість". Станція "брак" максимально поміщає 10 одиниць виробів, далі вироби рухаються на "вихід1", така ж місткість виробів і для станції "якість". Після накопичення вироби рухаються на "вихід2".

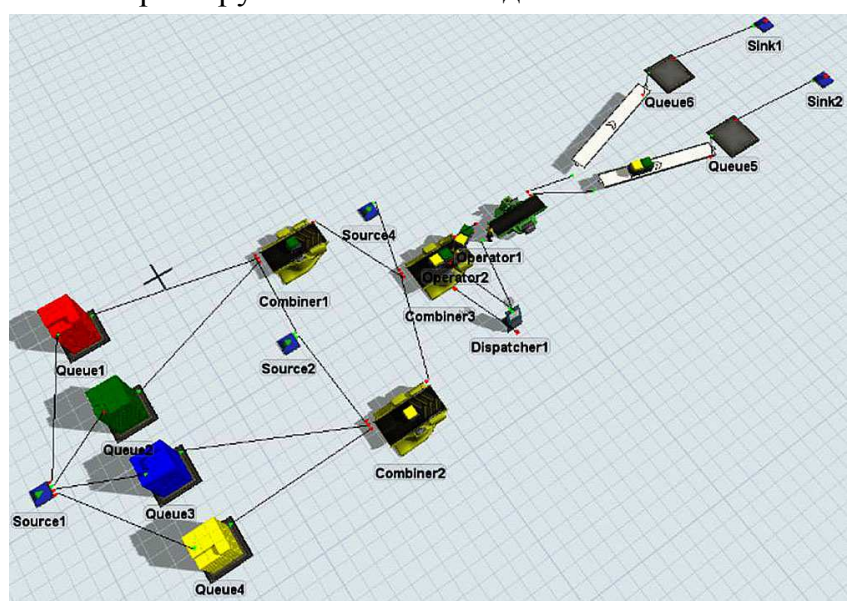

Рис. 3. Імітаційна модель технологічного процесу складання, відбраковування, упакування продукції на виробництві

Побудуємо імітаційну модель роботи виробництва. Для дослідження промислової лінії в середовищі FlexSim використано такі об'єкти: Source 1, 2, 3 - створення об'єктів, Queue 1, 2, 3, 4, 5, 6 - черга, пункт складання, Operator 1,2 - оператори, Conveyor 1,2 - конвеєри, Dispatcher - об'єкт, що призначений для регулювання роботи операторів, Вох - об'єкт сортування та складання, Pallet - позначення упаковки виробу, Tote - позначення ящика. Processor 1 - процесор, Combiner 1, 2, 3 - ком- 
байнер, Sink 1, 2 - вихід, точка зупинки процесу. Для цієї технологічної лінії Sink 1 - вихід бракованої продукції, Sink 2 - вихід якісної продукції. На рис. 3 подано розроблений нами процес імітаційного моделювання технологічного процесу пакування, а саме процесу оформлення упакування виробів та їх перевірки на якість.

Виріб, який позначили об'єктом Вох, рухається 3 джерела 1 (Source 1) до черги Queue 1. 3 черги Queue 1 i Queue 2 виріб "один" та виріб "два" надходять на комбайнер. На комбайнері Combiner 1 збираються проміжні вироби першого виду з деталей першого та другого видів. Також проміжні вироби другого виду складаються на комбайнері Combiner 2, але 3 деталей третього та четвертого виду. Третій комбайнер Combiner 3 поєднує проміжні вироби першого виду та проміжні вироби другого виду у підсумковий виріб. Оператори переносять виріб на спеціальну станцію, яка перевіряє якість виробів. Перевірку на якість проходять $95 \%$ виробів, які відправляються на станцію "якість". Тут можна розмістити десять одиниць готових виробів. Після цього вони відправляються на вихід 2, далі упаковуються і перевозяться. Така ж місткість виробів, десять одиниць, і для станції "брак". Після накопичення вироби рухаються на Sink 1 "вихід 1", далі браковані вироби рухаються на утилізацію. У процесі розроблення імітаційної моделі проаналізовано вплив різних даних як на кожен об'єкт зокрема, так і на систему загалом. На рис. 4 подано розроблену нами схему взаємозв'язків між параметрами моделі та відображення даних, які впливають на кожен об'єкт зокрема.

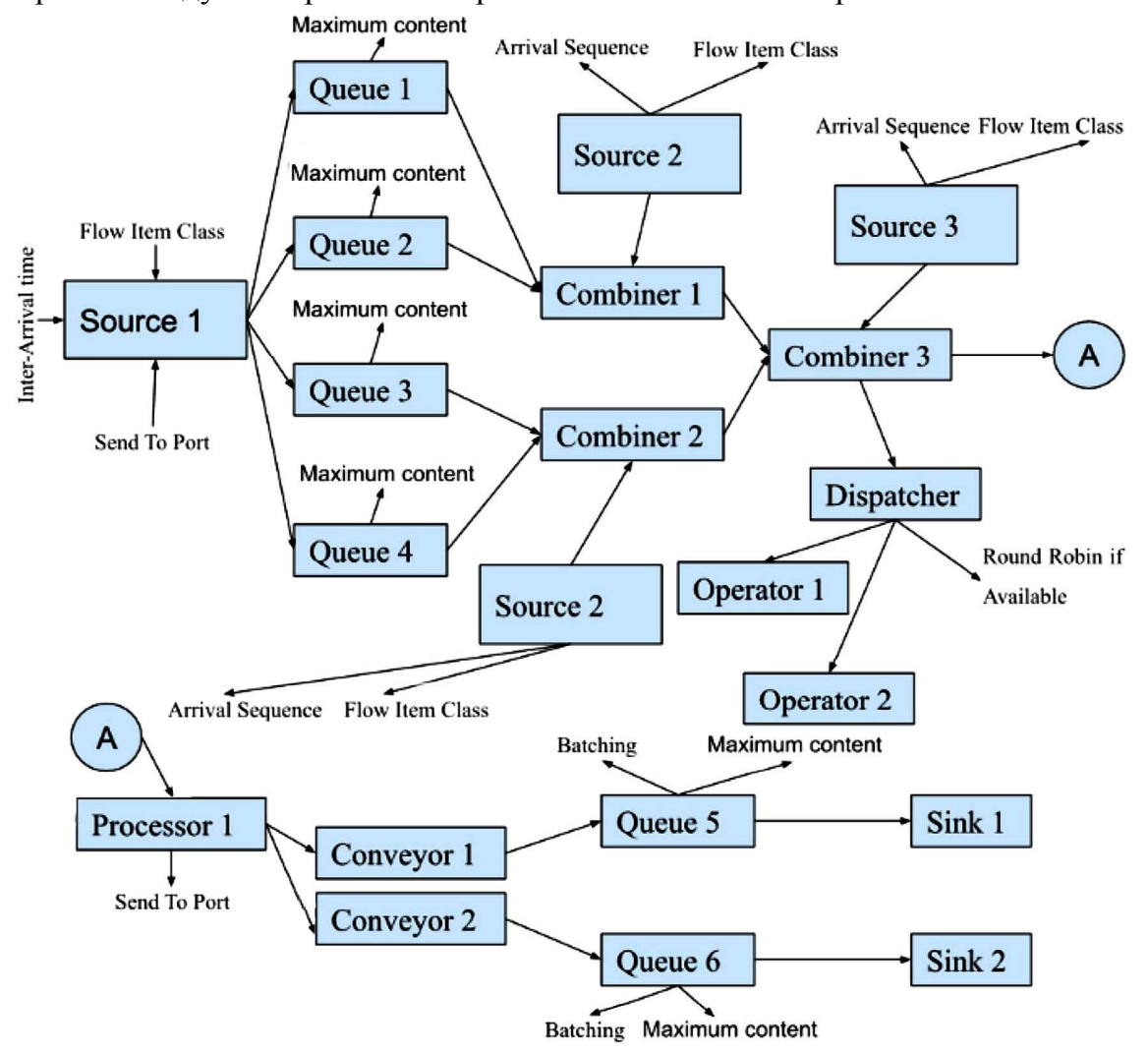

Рис. 4. Взаємозв'язки між об'єктами в процесі імітаційного моделювання технологічної лінії

Взаємозв'язки між різними об'єктами моделі дають можливість проаналізувати як можна змінити логіку процесу, щоб оптимізувати технологічний процес. Зазначимо, що першим важливим кроком є послідовне введення даних та визначення логіки руху об'єктів на кожному етапі моделювання цієї задачі. На рис. 4 бачимо вхідні параметри, які потрібно задати на першому етапі, a саме для об'єкта Source 1 за таким алгоритмом:

1. Визначення кількості об'єктів на вході. За постановкою задачі на вході маємо чотири види продукції. Цю логіку задаємо у властивостях джерела Source 1, а саме: Source - Triggers - On Creation - Set The Item Type and Color - Item type - duniform ( 1,4 , getstream (current)).

2. Для об'єкта Source 1 у розділі Flow задаємо принцип розподілу, логіку руху кожного об'єкта, а саме задаємо інформацію про порт для руху кожного об'єкта: Source - Flow - Send To Port - Port By Case (рис. 5).

3. Опція Inter - ArrivalTime дає змогу задати логіку і тип розподілу даних: Source - Inter-ArrivalTime.

4. Опція FlowItem Class дає змогу обрати вид об'єктів, наприклад, у нашому випадку обрано Вох.
5. Для Source 2 задана відповідна логіка:

- Source - Arrival Style - Arrival Sequence;

- Source - FlowItem Class - Tote.

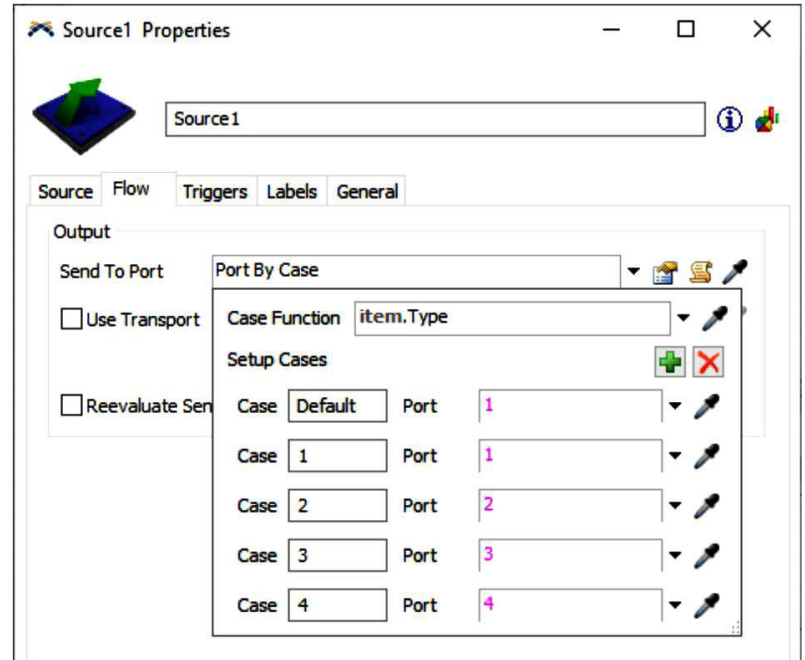

Рис. 5. Розподіл об'єктів із джерела Source 1 на відповідний порт 
Для нашої задачі використані два типи розподілу об'єктів на вході: експонеціального (рис. 6,a) та нормального (див. рис. 6,б).

\section{Inter-Arrivaltime}

exponential(0.0,10.0, getstream(current)) $\quad$ 国

\begin{tabular}{lll}
\hline Distribution & exponential \\
Location & 0.0 & \\
Scale & 10.0 & \\
Stream & getstream(current)
\end{tabular}

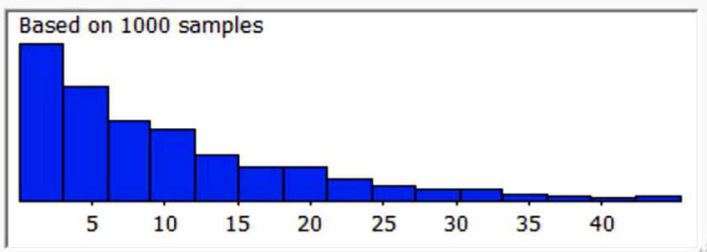

a)

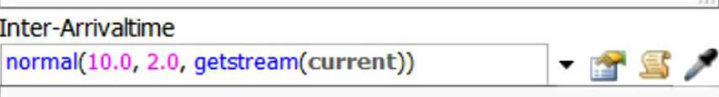

\begin{tabular}{|c|c|c|}
\hline Distribution & normal & $\checkmark$ \\
\hline Mean & 10.0 & \\
\hline Std Dev & 2.0 & \\
\hline Stream & getstream(current) & \\
\hline
\end{tabular}

б)

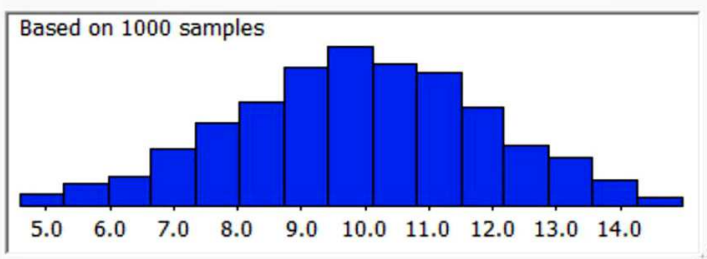

Рис. 6. Два типи розподілу об'єктів на вході: експоненціальний і нормальний

Обираємо Repeat Schedule / Sequence - це повторення розкладу, який задано в таблиці до моменту зупинки моделі. В Combiner 3 обираємо Use Transport у вкладці Flow. Наступний елемент Source 3, де задана відповідна логіка: Source - Arrival Style - Arrival Sequence, Source - FlowItem Class - Pallet. Логіка Dispatcher: Dispatcher - Pass To - Round Robin if Available.

6. Цей етап відповідає за відбраковування виробів. Вибираємо необхідні значення відсотків на відбраковування. Processor 1 має наступну логіку: Flow - By Percentage. Ha Port 1 надходить $5 \%$ одиниць виробів, на Port 2 подаємо $95 \%$ якісних виробів. На рис. 7 показано результат введення даних для об'єкта Processor 1.

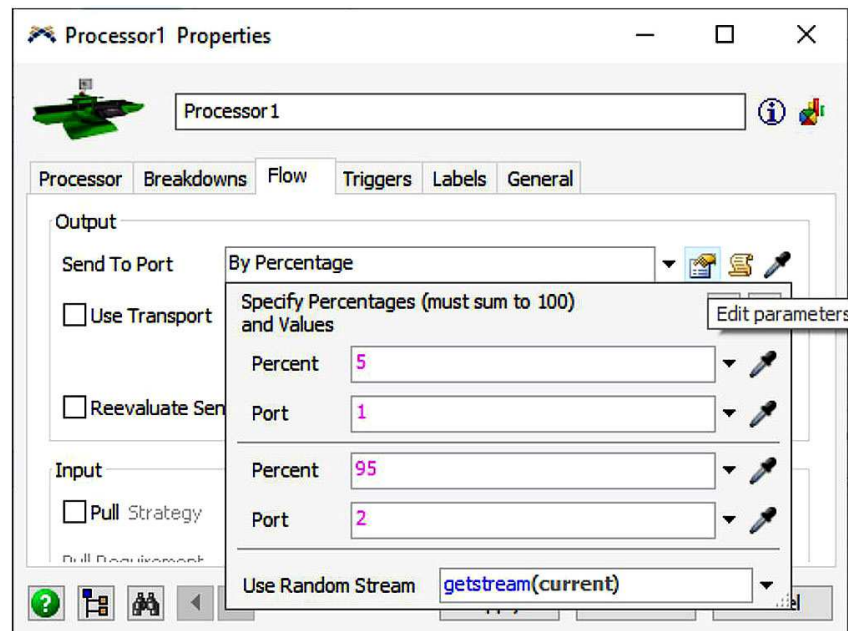

Рис. 7. Введення відсотків на відбракування виробів, визначення логіки об'єкта Processor 1
Для Conveyor 1, 2 залишаємо логіку за замовчуванням. Queue 5, 6 мають однакову логіку, а саме Maхimum Content - 10, тобто вмісткість виробів. Далі обиpaємо Perform batching, де Target Batch Size - 10. Perform batching відповідає за накопичення елементів потоку в пакет елементів, перш, ніж пропускати їх далі. Накопичення триває доти, доки не буде досягнуто цільовий розмір партії (Target Batch Size), а саме десять одиниць виробів. Проаналізувавши вхідні величини, ми зупинились на ефективності використання двох законів розподілу для даної складеної моделі, а саме показникового та нормального закону розподілу виробів, що надходять 3 джерела Source 1 i розподіляються між чотирма чергами. На рис. 8 продемонстровані графіки, які показують рівномірний розподіл виробів 3 джерела Source 1 на черги Queue 1, 2, 3, 4, 5, 6. Подані графіки відображають, що однакова кількість виробів (15 виробів) надходить на кожну чергу за певний період часу (8 c).

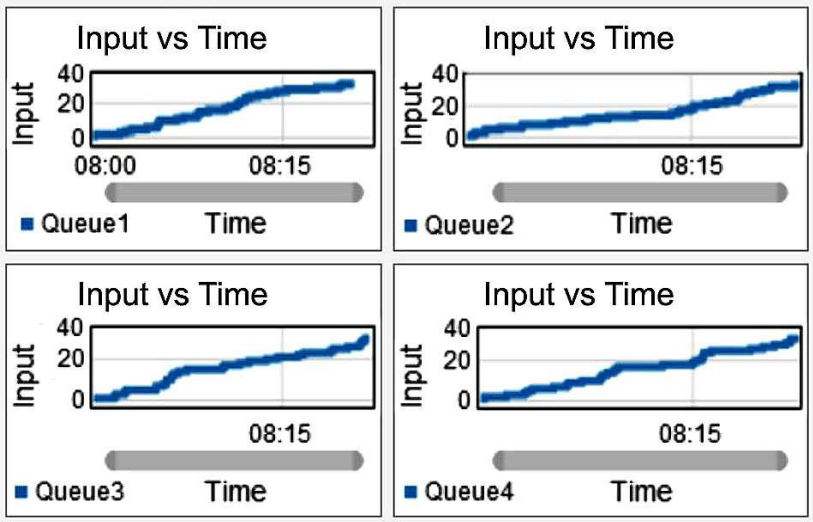

Рис. 8. Графіки, що демонструють рівномірний розподіл вхідних об'єктів за показниковим законом розподілу

Дослід показав, що для цього технологічного процесу оптимальним $\epsilon$ застосування показникового, тобто експоненціального, закону.

\section{Висновки}

Продемонстровано процес створення імітаційної моделі технологічного процесу виготовлення штампів у середовищі імітаційного моделювання FlexSim. Створено схему взаємозв'язків між об'єктами в досліджуваному процесі, яка наочно продемонструвала вплив вхідних даних як на кожен об'єкт окремо, так і на перебіг усього технологічного процесу.

Запропоновано послідовність задавання логіки для взаємодії об'єктів цього технологічного процесу. Розглянуто вплив типу розподілу об'єктів на станції, а саме показникового закону розподілу.

Результати досліджень продемонстрували ефективність застосування показникового закону розподілу виробів у технологічному процесі на виробництві, а саме на рис. 8 зображено графіки, що показують рівномірний розподіл виробів 3 джерела Source 1 на черги.

\section{References}

1. Hao Peng, \& Qiushi Zhu (2017). Approximate evaluation of average downtime under an integrated approach of opportunistic maintenance for multi-component systems. Computers \& Industrial Engineering, 109 , $335-346$. https://doi.org/10.1016/i.cie.2017.04.043.11

2. Ljaskovska, S., Martyn, Y., Malets, I., \& Prydatko, O. (2018). Information Technology of Process Modeling in the Multiparameter Systems. IEEE Second International Conference on Data Stream 
Mining \& Processing (DSMP), 177-182 https://doi.org/10.1109/DSMP.2018.8478498

3. Ljaskovska, S., Martyn, Y., Malets, I., \& Velyka, O. (2020). Optimization of Parameters of Technological Processes Means of the FlexSim Simulation Simulation Program, IEEE Third International Conference on Data Stream Mining \& Processing (DSMP), 391-397. https://doi.org/10.1109/DSMP47368.2020.9204029

4. Manavalan, E., \& Jayakrishna, K. (2019). A review of Internet of Things (IoT) embedded sustainable supply chain for industry 4.0 requirements $3(127)$, 925-953. https://doi.org/10.1016/j.cie.2018.11.030

5. Mustafa Fatih Yegul, Fatih Safa Erenay, Soeren Striepea, \& Mustafa Yavuza (2017). Improving configuration of complex production lines via simulation-based optimization. Computers \& Industrial Engineering 4(109), 295-312. https://doi.org/10.1016/j.cie.2017.04.019

6. Riko I Made, Chee Lip Gan, Liling Yan, Katherine Hwee Boon Kor, Hong Ling Chia, Kin Leong Pey, \& Carl V. Thompson. (2012). Experimental characterization and modeling of the mec- hanical properties of $\mathrm{Cu}-\mathrm{Cu}$ thermocompression bonds for threedimensional integrated circuits. Acta Materialia, 60(2), 578-587. https://doi.org/10.1016/j.actamat.2011.09.038

7. Sena Daş, G. (2017). New Multi objective models for the gate assignment problem. Computers \& Industrial Engineering, 109, 347-356. https://doi.org/10.1016/j.cie.2017.04.042

8. Smotr, O., Ljaskovska, S., Malets, I., \& Karabyn, O. (2020). Increasing the Animation Study Management Services Functioning Efficiency. IEEE Third International Conference on Data Stream Mining \& Processing (DSMP), 404-408. https://doi.org/10.1109/DSMP47368.2020.9204152

9. Sornettea, D., Maillart, T., \& Kröger, W. (2013). Exploring the limits of safety analysis in complex technological systems. International Journal of Disaster Risk Reduction, 6, 59-66. https://doi.org/10.1016/j.ijdrr.2013.04.002

10. Yang, T., Hou, Z., Liang, J., Gu, Y., \& Chao, X. (2020). Depth Sequential Information Entropy Maps and Multi-Label Subspace Learning for Human Action Recognition. IEEE Access, 8, 135118-135130. https://doi.org/10.1109/access.2020.3006067

O. T. Velyka1, S. E. Liaskovska1, O. O. Smotr' ${ }^{2}$, M. V. Boyko1

${ }^{1}$ Lviv Polytechnic National University, Lviv, Ukraine

${ }^{2}$ Lviv State University of Life Safety, Lviv, Ukraine

\section{SIMULATION MODELING OF TECHNOLOGICAL PROCESS OF MANUFACTURING IN FLEXSIM ENVIRONMENT}

The paper provides the analysis of the algorithm of creating the technological process in production using FlexSim simulation environment. Solution of the problem of sorting and packaging products is studied. A model of system behaviour, which allows identifying problem areas and abnormal situations in the production, is built. It is important to consider the input parameters of such task. For creating a simulation model of special technology complex a number of methods and tools for process modeling have been previously analyzed. The model created demonstrates that the choice of the indicator law of distribution is effective. We used it for the first step of this task for sorting products from the warehouse at the station. Using of the normal distribution law is suggested to sort the producers at the input step. The law of distribution is found to be important for the construction of simulation models to ensure uniform loading at stations. Part of the technological process of the equipment manufacture in production is considered. The stages of unloading, disassembly of pallets, rejection of products and ordering are analyzed. The process was modeled in the FlexSim environment, taking into account the given parameters and the relationships between them. A simulation model enabled analysing the stages of product distribution and choosing a more rational one. The analysis of the effectiveness of application of the exponential law of distribution of products from the warehouse at the station is performed in the work. In the process of developing a simulation model, the impact of different data on each object in particular and on the system as a whole was analyzed. A diagram of the correlation between the parameters of the model and the display of data that affect each object in particular was created. The correlation between the objects in the model allows analysing whether the process logic can be changed to optimize the process. An important step is to sequentially enter data and determine the logic of the movement of objects at each stage of modeling the task. We present the graphs showing the uniform distribution of products from the source to the queues. The graphs show that the same number of products arrives at each queue over a period of time.

Keywords: simulation model; FlexSim simulation environment; technological process; exponential distribution law; industry. 